\title{
Study of Inorganic Profiles of Street Cocaine Samples Using ICP-MS and ICP OES
}

\author{
Zanata B. Amorim, ${ }^{a, b}$ Maiara P. Machado, ${ }^{a}$ Mariana K. Moro, ${ }^{c}$ Laura O. Rebouças, ${ }^{a}$ \\ Bruna M. Dalfior, ${ }^{a}$ Wanderson Romão, ${ }^{b, c}$ Paulo Roberto Filgueiras, ${ }^{\circledR *, a}$ \\ Maria Tereza W. D. Carneiro ${ }^{\circledR a}$ and Geisamanda P. Brandão ${ }^{a}$
}

\author{
${ }^{a}$ Laboratório de Espectrometria Atômica (LEA)/LabPetro, Departamento de Química, \\ Universidade Federal do Espírito Santo (UFES), 29075-910 Vitória-ES, Brazil
}

${ }^{b}$ Instituto Federal do Espírito Santo, Soteco, 29106-010 Vila Velha-ES, Brazil

${ }^{c}$ Laboratório de Petroleômica e Forense/LabPetro, Departamento de Química, Universidade Federal do Espírito Santo (UFES), 29075-910 Vitória-ES, Brazil

\begin{abstract}
Determining inorganic constituents in illicit drugs can indicate its purity and presence of adulterants. In this study, we analyzed 52 street cocaine samples, seized in three different regions of Espírito Santo, state of Brazil. Inductively coupled plasma optical emission spectrometry was used to determine $\mathrm{Al}, \mathrm{Ca}, \mathrm{Cu}, \mathrm{Fe}, \mathrm{Mn}, \mathrm{Mg}, \mathrm{Zn}$ concentrations and inductively coupled plasma mass spectrometry to determine $\mathrm{Mo}, \mathrm{Co}, \mathrm{Pb}$ and $\mathrm{P}$ concentrations. From analyte recovery tests, the accuracy was considered acceptable and the proposed method satisfactory. Most of the samples exhibited a relatively homogeneous inorganic profile with similar concentrations of investigated elements, however some samples had very discrepant concentrations. High concentrations of Al, $\mathrm{Ca}, \mathrm{Fe}, \mathrm{Mg}, \mathrm{Mn}$, and $\mathrm{P}$ were found, indicating that adulterants such as gypsum, marble powder, limestone, cement, and others must be used to increase the profitability of the illicit drug market.
\end{abstract}

Keywords: inorganic elements, cocaine, ICP-MS, ICP OES, multivariate analysis

\section{Introduction}

The abuse and use of illicit drugs are one of the biggest challenges facing society in the XXI century. ${ }^{1}$ These drugs are generally used for pleasurable effects, since most of them affect the central nervous system, altering the state of consciousness, mood, and behavior of users. These changes can lead to either euphoria or depression; however, can also adversely affect the health of users, their family or community, as well as the social development, stability and safety, creating significant risks and problems. ${ }^{2}$

The United Nations Office on Drugs and Crimes (UNODC) reported that coca and cocaine-related substances were the drugs with the second largest quantities seized in 2017, over the world. The global quantity cocaine production has risen by 50 per cent over the past decade, reaching record levels in 2017, which was mainly due to the production increase in Colombia, which more than quadrupled over the period 2013-2017. It is also estimated

*e-mail: paulo.filgueiras@ufes.br, filgueiras.pr@gmail.com that 18.1 million people were past-year users of the drug over the world, in the same year. ${ }^{3}$

For those reasons, the analysis of abuse drugs in forensic chemistry is a highly valuable research topic, because the reduction of drug traffics and the number of chemical dependents has become current challenges for society. ${ }^{4}$ Cocaine is a drug of plant origin and contains alkaloids, which have a considerable interest in forensic chemistry research. ${ }^{5}$ Cocaine (benzoylmethylecgonine) is a tropane alkaloid (8-methyl-8-azabicyclo[3,2,1] octane) with a bicyclic structure, formed from the primary alkaloid present in Erythroxylum coca Lamarck, a native bush, found in some Andean countries such as Peru, Bolivia and Colombia. ${ }^{5-7}$ Cocaine primarily acts stimulating the central nervous system, followed by depression. This explains why cocaine addicts increasingly crave the drug in an attempt to re-establish the initial euphoric state. ${ }^{2}$

Street cocaine is sold illicitly and contains cocaine hydrochloride in addition to many other substances, such as contaminants, adulterants, and diluents, and is rarely found in a $100 \%$ pure state. ${ }^{8,9}$ In Brazil, the purity of seized street cocaine ranges up to $85 \%,{ }^{10}$ which is similar to France 
(up to $88 \%),{ }_{11}^{11}$ while the seized cocaine blocks have a higher purity range ( 80 to $90 \%$ ). ${ }^{12}$ Cocaine impurities may originate from coca leaves during the production process. Diluents and adulterants are added to cocaine, to increase the drug amounts and, thus, the sales profit. These substances are cheaper than pure cocaine and, besides diluting the drug, may act synergistically (adulterants) producing similar effects than cocaine..$^{13-15}$ During the production process, organic solvents and inorganic compounds, such as calcium oxide (quicklime), sodium carbonate, hydrochloric acid, and sulfuric acid are used to extract cocaine from coca leaves. Extraction process produces a cocaine base paste, which is usually treated with hydrochloric acid and potassium permanganate, to produce cocaine hydrochloride, the active cocaine ingredient. ${ }^{16}$ Inorganic diluents, such as gypsum plaster, limestone, marble dust, calcium sulfate, and phosphate and talcum powder, are used more frequently than organic diluents such as starch, sugar, wheat flour, ${ }^{17}$ making essential to quantify certain elements and identify the presence of inorganic compounds.

Rarely is found $100 \%$ purity cocaine, because generally contaminants derived from refining and adulterants are present, sometimes in high concentration. The different components found in samples can contribute to determine its origin. The analytical information obtained through the analysis of a seized cocaine sample becomes very important for use in investigations by the police intelligence, also as an evidence for legal purposes. ${ }^{15}$

Besides, knowing the type of adulteration by quantifying the concentration of inorganic elements can also generate data to be used in public policies to prevent trafficking. It can help to elucidate the drug route inside the State, from its origin to the end user, through adulteration processes. It can also assist in the treatment of drug users, since several elements quantified in the study are harmful to health. In addition, knowing the presence/type of contaminants is important because diluting substances such as talc, plaster, lime and chalk, used to increase the volume of the drug, are not absorbed and can cause chronic obstructive pulmonary diseases, such as silicosis which causes the hardening of the lung. ${ }^{17}$

Many analytical techniques have been applied to determine the active ingredients, adulterants, diluents, and impurities in illicit drug samples. For elemental analysis electrothermal atomic absorption spectrometry (ET AAS), flame atomic absorption spectrometry (FAAS), inductively coupled plasma optical emission spectrometry (ICP OES) and inductively coupled plasma mass spectrometry (ICPMS) can be employed; however, few studies about the application of these techniques to cocaine analysis have been reported. ${ }^{18-23}$
Bermejo-Barrera et al. ${ }^{18-22}$ performed cocaine pasta base analysis by diluting the sample (20 times) with $3.5 \% \mathrm{v} \mathrm{v}^{-1}$ nitric acid, to determine $\mathrm{Cr}, \mathrm{Ag}, \mathrm{Mn}, \mathrm{Ni}$ and $\mathrm{Pb}$, in cocaine samples with, approximately, $90 \%$ of purity, by ET AAS, F AAS and FAES (flame atomic emission spectrometry). Magalhães et al. ${ }^{23}$ diluted the sample (100 times) with $10 \% \mathrm{v} \mathrm{v} \mathrm{v}^{-1}$ nitric acid to determine $\mathrm{Ca}, \mathrm{Mg}, \mathrm{Na}, \mathrm{P}, \mathrm{Al}, \mathrm{Fe}, \mathrm{Mn}$ and $\mathrm{Zn}$ in street cocaine samples, by ICP OES. However, the street cocaine samples were not wholly solubilized, and only the soluble fraction was analyzed. However, we emphasize that to investigate the substances used in street cocaine production or dilution, it is essential to decompose and solubilize the samples entirely before elements determination.

Much information can be obtained by determination of certain elements in street cocaine. Statistical tools can be applied to facilitate the interpretation of results. ${ }^{8}$ Statistic treatments of data have been successfully applied in forensic studies to obtain information about the origin and adulteration of illicit substances ${ }^{20,21}$ and other forensic evidence. ${ }^{22}$ Multivariate analysis is widely used for chemical data treatment. In multivariate analysis, correlations between variables are used to extract a large amount of information, which is often impossible to achieve by analyzing each variable individually. ${ }^{24-26}$

Some statistic tools, widely used for data treatment, include principal component analysis (PCA), hierarchical cluster analysis (HCA), Pearson's correlation coefficient (r) and boxplot. ${ }^{27-29}$ PCA is an unsupervised learning that attempts to identify patterns by reducing the dimensionality of the data for easier visualization. The new variables, called principal components, must explain the variance of data with minimal loss of information. HCA is a hierarchical process in which each step of the hierarchical matrix and the data matrix are decreased to one dimension, by progressively joining similar pairs until all of the points are joined into a single group. The purpose of HCA is to represent the data in a two-dimensional space to determine clustering and natural patterns. The results are presented as dendrograms, where samples are grouped according to their similarities. ${ }^{29}$

Pearson's correlation coefficient (r), or the correlation coefficient, is used to measure the degree of linear correlation between two quantitative variables. It is a dimensionless measure, ranging between +1.0 and $-1.0 .^{29}$ Boxplot graphically demonstrates the central position of the data (median) and the tendency, as well as any indication of symmetry or asymmetry of the data. Unlike many other statistical tools, boxplot shows outliers and can easily compare the samples. ${ }^{29}$

This study aimed to develop a method to determine Al, $\mathrm{Ca}, \mathrm{Cu}, \mathrm{Fe}, \mathrm{Mn}, \mathrm{Mg}$ and $\mathrm{Zn}$ by ICP OES and $\mathrm{Mo}, \mathrm{Co}, \mathrm{Pb}$ and $\mathrm{P}$ by ICP-MS, in street cocaine samples. Some statistical 
tools were used to analyze the obtained data to verify correlations and patterns and find similar and discrepant characteristics between the samples.

\section{Experimental}

Instrumentation

The $\mathrm{Al}, \mathrm{Ca}, \mathrm{Cu}, \mathrm{Fe}, \mathrm{Mn}, \mathrm{Mg}$ and $\mathrm{Zn}$ determination was performed using an ICP OES spectrometer, Optima 7000 Dual View model (PerkinElmer, Waltham, USA), and the $\mathrm{Mo}, \mathrm{Co}, \mathrm{Pb}$ and $\mathrm{P}$ determination was performed using an ICP-MS spectrometer, NexIon 300D model (PerkinElmer, Waltham, USA).

Cocaine samples were acid decomposed using a microwave oven equipped with closed PFA vessels (Multiwave 3000) and a rotor (16MF100/HF100) (Anton Paar, Graz, Austria). Cocaine samples were weighed using an analytical balance ED224S (Sartorius Weighing Technology, Goettingen, Germany) with an accuracy of $\pm 0.0001 \mathrm{~g}$.

\section{Reagents}

All solutions were prepared using ultrapure water with $18.2 \mathrm{M} \Omega \mathrm{cm}$ of resistivity (PURELAB Ultra Mk 2, ELGA, High Wycombe, UK). The $65 \% \mathrm{~m} \mathrm{~m}^{-1} \mathrm{HNO}_{3}$, purchase from Synth (São Paulo, Brazil), was purified in an acid distiller (Sub-boiling Distillacid BSB939 IR, BERGHOF, Berchtesgaden, Germany) and used after adequate dilution.

Standard solutions of $\mathrm{Ca}, \mathrm{Cu}, \mathrm{Fe}, \mathrm{Mn}, \mathrm{Mg}, \mathrm{Zn}, \mathrm{Mo}, \mathrm{Co}$, and $\mathrm{Pb}$ were prepared in $2 \% \mathrm{v} \mathrm{v}^{-1} \mathrm{HNO}_{3}$, by appropriate dilution of a multielement solution $1000 \mathrm{mg} \mathrm{L}^{-1}$ (PlasmaCAL QC Standard 3 140-102-051, SCP Science, Quebec, Canada). $\mathrm{Al}$ and $\mathrm{P}$ standard solutions were prepared in $2 \% \mathrm{v} \mathrm{v}^{-1} \mathrm{HNO}_{3}$, by appropriate dilution of mono-element standard solutions $1000 \mathrm{mg} \mathrm{L}^{-1}$, purchased from SCP Science (Quebec, Canada). The concentration of the standard solutions for Al, $\mathrm{Ca}, \mathrm{Cu}, \mathrm{Fe}, \mathrm{Mn}, \mathrm{Mg}$ and $\mathrm{Zn}$ analytical curves were 0,50 , 100,500 and $1000 \mu \mathrm{g} \mathrm{L}^{-1}$. The concentration of the standard solutions for $\mathrm{Mo}, \mathrm{Co}, \mathrm{Pb}$ and $\mathrm{P}$ analytical curves were $0,0.5$, 1, 2, 5, 10 and $20 \mu \mathrm{g} \mathrm{L}{ }^{-1}$. Argon (99.9992\%) was used as plasma, nebulizer, and auxiliary gases. Nitrogen (99.99\%) was used as shear gas and nitrogen (99.9929\%) as purging gas in ICP OES. All gases were purchased from Air Products (São Paulo, Brazil).

\section{Samples}

The Civil Police of the State of Espírito Santo-Brazil (in accordance to the cooperation agreement No. 1007/2012) provided fifty-two cocaine samples, seized in March 2014, in twenty cities, over three geographic regions of the state. Region 1, called metropolitan area, location in which the city Vitória, capital of Espírito Santo state, is located, where eighteen samples were seized; region 2, north of the state, where sixteen of the samples were seized; and region 3, the south of the state, where eighteen of the samples were seized.

\section{Procedure}

Sample preparation consisted of decomposition of $0.1 \mathrm{~g}$ of sample, with $6 \mathrm{~mL}$ of $5 \% \mathrm{v} \mathrm{v}^{-1} \mathrm{HNO}_{3}$, in closed-vessel in microwave system. The heating program consisted of two stages: at $130{ }^{\circ} \mathrm{C}$ for $10 \mathrm{~min}$, followed by $180{ }^{\circ} \mathrm{C}$ for $10 \mathrm{~min}$. After decomposition, samples were transferred to polypropylene flasks and diluted to $15.0 \mathrm{~mL}$, using ultrapure water.

$\mathrm{Al}, \mathrm{Ca}, \mathrm{Cu}, \mathrm{Fe}, \mathrm{Mn}, \mathrm{Mg}$ and $\mathrm{Zn}$ concentrations were determined by ICP OES, and $\mathrm{Mo}, \mathrm{Co}, \mathrm{Pb}$ and $\mathrm{P}$ by ICP-MS. The emission lines were selected according to Bermejo-Barrera et al. ${ }^{21}$ or by considering those with higher sensitivity and absence of interferences. For ICP-MS determinations, the more abundant isotopes or suffering low interference, were selected. ${ }^{30-33}$ The ICP OES and ICP-MS operations conditions, accessories, spectral lines and isotopes determined are cited in Tables 1 and 2, respectively.

Table 1. ICP OES operational parameters

\begin{tabular}{|c|c|c|}
\hline \multicolumn{2}{|l|}{ Plasma power / W } & 1357 \\
\hline \multicolumn{2}{|c|}{ Plasma gas flow rate / $\left(\mathrm{L} \mathrm{min}^{-1}\right)$} & 15 \\
\hline \multicolumn{2}{|c|}{ Auxiliary gas flow rate / $\left(\mathrm{L} \mathrm{min}{ }^{-1}\right)$} & 0.2 \\
\hline \multicolumn{2}{|c|}{ Nebulizer gas flow rate / $\left(\mathrm{L} \mathrm{min}{ }^{-1}\right)$} & 0.55 \\
\hline \multicolumn{2}{|c|}{ Purge nitrogen $/\left(\mathrm{mL} \mathrm{min}^{-1}\right)$} & 1.5 \\
\hline \multicolumn{2}{|l|}{ Nebulizer } & GemCone \\
\hline \multicolumn{2}{|l|}{ Spray chamber } & cyclonic \\
\hline \multicolumn{2}{|l|}{ Replicates } & 3 \\
\hline \multicolumn{2}{|l|}{ Injector tube / mm } & 0.8 \\
\hline \multicolumn{2}{|l|}{ Torch } & 1 Slott \\
\hline \multicolumn{2}{|l|}{ Plasma view } & axial \\
\hline \multicolumn{2}{|c|}{ Sample uptake rate $/\left(\mathrm{mL} \mathrm{min}^{-1}\right)$} & 1.5 \\
\hline \multirow{7}{*}{ Spectral lines / nm } & $\mathrm{Al}(\mathrm{I})$ & 396.153 \\
\hline & $\mathrm{Ca}$ (II) & 422.673 \\
\hline & $\mathrm{Cu}(\mathrm{I})$ & 327.393 \\
\hline & $\mathrm{Fe}(\mathrm{II})$ & 259.939 \\
\hline & $\mathrm{Mn}$ (II) & 257.610 \\
\hline & $\mathrm{Zn}(\mathrm{II})$ & 213.857 \\
\hline & $\mathrm{Mg}$ (II) & 279.077 \\
\hline
\end{tabular}

(I): atomic line; (II): ionic line. 
Table 2. ICP-MS operational parameters

\begin{tabular}{lc}
\hline Nebulizer gas flow rate / $\left(\mathrm{L} \mathrm{min}^{-1}\right)$ & 1.02 \\
Auxiliary gas flow rate / $\left(\mathrm{L} \mathrm{min}^{-1}\right)$ & 1.20 \\
Plasma gas flow rate / $\left(\mathrm{L} \mathrm{min}^{-1}\right)$ & 16 \\
Lens voltage / V & 6 \\
RF energy ICP / W & 1550 \\
Voltage phase analog / V & 1625 \\
Voltage phase pulse / V & 950.00 \\
Sampler cone & $\mathrm{Ni}$ \\
Skimmer cone & $\mathrm{Ni}$ \\
Nebulizer & Meinhard concentric \\
Sample uptake rate / $\left(\mathrm{mL} \mathrm{min}{ }^{-1}\right)$ & 0.7 \\
Mode & peak hopping \\
& ${ }^{59} \mathrm{Co}$ \\
Isotope & ${ }^{208} \mathrm{~Pb}$ \\
& ${ }^{95} \mathrm{Mo}$ \\
\hline
\end{tabular}

ICP: inductively coupled plasma.

\section{Statistical analysis}

Statistical analysis of data obtained was performed using the software MATLAB. ${ }^{34}$ To obtain a separation of the samples by similarity, based on elements concentrations determined, HCA and PCA were performed, after data normalization. The separation between cocaine samples was calculated by the Euclidean distance, and the agglomeration by Ward's method. Person's correlation coefficient was used to measure the relationship, or association, between the elements in the samples. Lastly, a boxplot was built to show the distribution of the total inorganic mass in the samples, according to the seizure region.

\section{Results and Discussion}

\section{Sample preparation}

Initially, sample preparation procedures were performed according to previous studies. ${ }^{16-20}$ A total of $2 \mathrm{~mL}$ of $35 \% \mathrm{v} \mathrm{v}^{-1} \mathrm{HNO}_{3}$ was added to $0.5 \mathrm{~g}$ of cocaine sample and the solution diluted to $10 \mathrm{~mL}$. However, this procedure was unsatisfactory since the samples were not wholly solubilized, which is usually necessary for determining inorganic constituents. Sample solubilization with methanol was also investigated, which was also ineffective at complete solubilizing the samples.

In previous researches, ${ }^{16-20}$ it was observed that highly pure cocaine samples were soluble in water and ethanol.
However, the drug samples analyzed in the present study were insoluble in the same media, indicating the presence of high quantities of insoluble adulterants or diluents. As a consequence, different sample preparation procedures were investigated using direct solubilization and acid decomposition assisted by microwave radiation. Different sample quantities $(0.050,0.100,0.200$ and $0.500 \mathrm{~g})$ and $6 \mathrm{~mL}$ of $\mathrm{HNO}_{3}$ at different concentration $(5,10,30,40$ and $50 \% \mathrm{v} \mathrm{v}^{-1}$ ) were tested.

Most samples treated with $\mathrm{HNO}_{3}$ solution, without submission to microwave decomposition (direct solubilization), were not wholly solubilized, regardless of the acid concentration and sample mass used. Therefore, decomposition of samples was tested using the same sample masses and $\mathrm{HNO}_{3}$ solution concentrations. Six milliliters of $5 \% \mathrm{v} \mathrm{v}^{-1} \mathrm{HNO}_{3}$ were enough to completely decompose most of the samples, regardless of the mass used, so this acid concentration was chosen. The sample solution was then diluted to $15.0 \mathrm{~mL}$ with ultrapure water. Since part of the acid is consumed during decomposition process, the final acidity of the sample solutions is below $2 \% \mathrm{v} \mathrm{v}^{-1}$, which does not usually cause spectral interferences or instrumentation problem during the analysis. After evaluation and choose of the acid concentration adequate for decomposition, the solutions with different amount of sample mass were analyzed. Using $0.05 \mathrm{~g}$ of cocaine, the analytical signal was very low and close to the limit of quantification (LOQ) while using $0.1 \mathrm{~g}$ the signals were adequate for analytes quantifications.

\section{Analytical figures of merit}

Analytes recovery tests were performed to verify if the sample preparation procedures were adequate for $\mathrm{Al}, \mathrm{Ca}$, $\mathrm{Cu}, \mathrm{Fe}, \mathrm{Mn}, \mathrm{Mg}$ and $\mathrm{Zn}$ determination by ICP OES and $\mathrm{Mo}, \mathrm{Co}, \mathrm{Pb}$ and $\mathrm{P}$ determinations by ICP-MS in cocaine samples. Thus, $\mathrm{Al}, \mathrm{Ca}, \mathrm{Cu}, \mathrm{Fe}, \mathrm{Mn}, \mathrm{Mg}$, and $\mathrm{Zn}$ were added to obtain $100 \mathrm{ng} \mathrm{mL} \mathrm{mL}^{-1}$ of these elements in the spiked sample solution in four street cocaine samples (A, B, C, and $\mathrm{D}$ ) for ICP OES analysis, while $\mathrm{Mo}, \mathrm{Co}, \mathrm{Pb}$, and $\mathrm{P}$ were added to obtain $10 \mathrm{ng} \mathrm{mL}^{-1}$ of these elements in the spiked sample solution in three of them for ICP-MS analysis.

Recovery values (Table 3) approached $100 \%$ for most of the studied elements, except for one sample, where Ca exhibited a recovery $(186 \%)$ much higher than the acceptable range (80-110\%). ${ }^{35,36}$ This may have been caused by the high Ca content in D sample that saturated signal. ${ }^{16}$ Thus, the recovery values (Table 3 ) indicated that sample preparation procedures and optimized analysis conditions used in this study were adequate for determining the investigated elements in the street cocaine samples. 
Table 3. Recovery values of $\mathrm{Al}, \mathrm{Ca}, \mathrm{Cu}, \mathrm{Fe}, \mathrm{Mn}, \mathrm{Mg}, \mathrm{Zn}, \mathrm{P}, \mathrm{Co}, \mathrm{Pb}$ and Mo spiked in street cocaine samples

\begin{tabular}{lcccc}
\hline \multirow{2}{*}{ Analyte } & \multicolumn{4}{c}{ Recovery value / \% } \\
\cline { 2 - 5 } $\mathrm{Al}$ & $\mathrm{A}$ & $\mathrm{B}$ & $\mathrm{C}$ & $\mathrm{D}$ \\
\hline $\mathrm{Ca}$ & 117 & 90.9 & 95.0 & 118 \\
$\mathrm{Cu}$ & 95.9 & 84.9 & 111 & 186 \\
$\mathrm{Fe}$ & 105 & 93.3 & 104 & 108 \\
$\mathrm{Mn}$ & 91.4 & 88.1 & 99.3 & 107 \\
$\mathrm{Mg}$ & 94.0 & 82.7 & 96.7 & 103 \\
$\mathrm{Zn}$ & 93.3 & 71.3 & 95.8 & 106 \\
$\mathrm{P}$ & 94.9 & 86.3 & 94.5 & 106 \\
$\mathrm{Co}$ & 91.9 & 87.3 & 104 & 108 \\
$\mathrm{~Pb}$ & 87.8 & 104 & 108 & - \\
$\mathrm{Mo}$ & 79.4 & 105 & 108 & - \\
\hline $\mathrm{Co}$ & 97.2 & 120 & 104 & - \\
\hline
\end{tabular}

$\mathrm{Co}, \mathrm{Pb}, \mathrm{Mo}$ in sample $\mathrm{D}$ were not determined.

As expected, the determination coefficient $\left(\mathrm{R}^{2}\right)$ of calibration curves were typically greater than 0.999 . The limit of detection (LODm) and the limit of quantification (LOQm) of the analytical method were calculated according to Instituto Nacional de Metrologia, Qualidade e Tecnologia (INMETRO), ${ }^{37}$ using equations 1 and 2, respectively, and considering the curve sensibility, the sample mass and the final volume used. The obtained LODm and LOQm, presented in Table 4, were inferior to values reported ${ }^{18,21}$ and were adequate for the proposed determinations.

$$
\begin{aligned}
& \mathrm{LODm}=\overline{\mathrm{X}}+3 \mathrm{~s} \\
& \mathrm{LOQm}=\overline{\mathrm{X}}+10 \mathrm{~s}
\end{aligned}
$$

where $\overline{\mathrm{X}}$ is the average value of the blank samples and $\mathrm{s}$ is the sample standard deviation of the blank samples.

Table 4. Limits of detection (LODm) and quantification (LOQm) of the proposed method

\begin{tabular}{lcc}
\hline Analyte & LODm & LOQm \\
\hline $\mathrm{Al} /\left(\mu \mathrm{g} \mathrm{g}^{-1}\right)$ & 0.027 & 0.090 \\
$\mathrm{Ca} /\left(\mu \mathrm{g} \mathrm{g}^{-1}\right)$ & 0.79 & 2.65 \\
$\mathrm{Cu} /\left(\mu \mathrm{g} \mathrm{g}^{-1}\right)$ & 0.037 & 0.13 \\
$\mathrm{Fe} /\left(\mu \mathrm{g} \mathrm{g}^{-1}\right)$ & 0.13 & 0.43 \\
$\mathrm{Mn} /\left(\mu \mathrm{g} \mathrm{g}^{-1}\right)$ & 0.031 & 0.11 \\
$\mathrm{Mg} /\left(\mu \mathrm{g} \mathrm{g}^{-1}\right)$ & 0.51 & 1.71 \\
$\mathrm{Zn} /\left(\mu \mathrm{g} \mathrm{g}^{-1}\right)$ & 0.26 & 0.87 \\
$\mathrm{P} /\left(\mathrm{ng} \mathrm{g}^{-1}\right)$ & 62.8 & 209.3 \\
$\mathrm{Co} /\left(\mathrm{ng} \mathrm{g}^{-1}\right)$ & 0.24 & 0.80 \\
$\mathrm{~Pb} /\left(\mathrm{ng} \mathrm{g}^{-1}\right)$ & 7.65 & 25.2 \\
$\mathrm{Mo} /\left(\mathrm{ng} \mathrm{g}^{-1}\right)$ & 17.9 & 59.6 \\
\hline
\end{tabular}

\section{Analytes determination in the analyzed samples}

Using the proposed sample preparation procedure, 52 street cocaine samples were prepared in triplicate and analyzed. The average of the obtained results and the relative standard deviation (RSD) are presented in Table 5. The RSD is defined as the ratio between the standard deviation and the mean, expressing the extent of variability in relation to the mean. As can be seen in Table 5, most measurements had satisfactory repeatability $(\mathrm{RSD}<5 \%) .{ }^{37}$ Only a few elements showed high RSD for certain samples. $\mathrm{Cu}$ was the element that most presented results with RSD above 5\%, but due to its low concentration a greater range of RSD is accepted. ${ }^{37}$

Using Pearson's correlation coefficient, concentrations of the investigated elements were correlated (Table 6) to determine relations between them and suggest chemicals used in production or dilution of cocaine. As can be seen in Table 6, most of the elements are not correlated to each other, since $\mathrm{r}$ values were close to zero. Only the pairs $\mathrm{Al}-\mathrm{Cu}, \mathrm{Fe}-\mathrm{Cu}, \mathrm{Mn}-\mathrm{Cu}$, and $\mathrm{Fe}-\mathrm{Mn}$, showed high correlations, with $\mathrm{r}>0.7$. The pairs Al-Mn, Al-Fe, and Ca-P, showed moderate correlations, with $\mathrm{r}$ higher than 0.6.

$\mathrm{Ca}, \mathrm{Mg}, \mathrm{P}, \mathrm{Al}$ and $\mathrm{Fe}$ showed higher concentrations, comparing to the other elements (Table 5), indicating that they may be part of the chemical composition of the adulterants added to the drug. Chan et al. ${ }^{38}$ analyzed inorganic compounds in heroin samples and also found $\mathrm{Ca}, \mathrm{Mg}$ and $\mathrm{Fe}$ present at relatively higher levels, besides $\mathrm{Na}$ and K elements.

$\mathrm{Ca}$ concentrations ranged from around $20 \mu \mathrm{g} \mathrm{g}^{-1}$ to higher than $50000 \mu \mathrm{g} \mathrm{g}^{-1}$ (saturated signal), presenting the most significant concentrations among all elements. Six samples from region 1 (R1-d, R1-f, R1-g, R1-j, R1-p and R1-q), three from region 2 (R2-a, R2-i and R2-n) and six from region 3 (R3-a, R3-b, R3-c, R3-g, R3-i and R3-q) exhibited high concentrations of $\mathrm{Ca}$, over $1000 \mu \mathrm{g} \mathrm{g}^{-1}$, which could be related to the use of calcium oxide (quicklime) in cocaine refining or to the use of some diluents as gypsum, limestone and marble powder.

$\mathrm{Mg}$ concentrations ranged from values below the detection limit to $45870 \mu \mathrm{g} \mathrm{g}^{-1}$. Two samples from region 1 (R1-f and R1-g), one from region 2 (R2-n) and three from regions 3 (R3-b, R3-h and R3-j) exhibited high concentrations of $\mathrm{Mg}$, over $1000 \mu \mathrm{g} \mathrm{g}^{-1}$, which could be related to addition of talcum powder $\left(\mathrm{Mg}_{3} \mathrm{Si}_{4} \mathrm{O}_{10}(\mathrm{OH})_{2}\right)$ as cocaine diluent. The high $\mathrm{Mg}$ concentrations in regions R1-f and R1-g, R2-n and R3-b can also be related to the addition of limestone as a diluent, since those samples also presented high $\mathrm{Ca}$ concentrations. 
Table 5. Average concentrations of $\mathrm{Al}, \mathrm{Ca}, \mathrm{Cu}, \mathrm{Fe}, \mathrm{Mn}, \mathrm{Mg}, \mathrm{Zn}, \mathrm{Co}, \mathrm{Mo}, \mathrm{Pb}$ and $\mathrm{P}$ and relative standard deviation (RSD)

\begin{tabular}{|c|c|c|c|c|c|c|c|c|c|c|c|c|c|c|c|c|c|c|c|c|c|c|}
\hline \multirow[b]{2}{*}{ ample } & \multicolumn{22}{|c|}{ Concentration } \\
\hline & $\begin{array}{c}\mathrm{Al} / \\
\left(\mu \mathrm{g} \mathrm{g}^{-1}\right)\end{array}$ & $\mathrm{R}$ & $\begin{array}{c}\mathrm{Ca} / \\
\left(\mu \mathrm{g} \mathrm{g}^{-1}\right) \\
\mathrm{F}\end{array}$ & & $\begin{array}{c}\mathrm{Cu} / \\
\left(\mu \mathrm{g} \mathrm{g}^{-1}\right)\end{array}$ & RSD & $\begin{array}{c}\mathrm{Fe} / \\
\left(\mu \mathrm{g} \mathrm{g}^{-1}\right)\end{array}$ & & $\begin{array}{c}\mathrm{Mn} / \\
\left(\mu \mathrm{g} \mathrm{g}^{-1}\right)\end{array}$ & $\mathrm{R}$ & $\begin{array}{c}\mathrm{Mg} / \\
\left(\mu \mathrm{g} \mathrm{g}^{-1}\right)\end{array}$ & $\mathrm{r}$ & $\begin{array}{c}\mathrm{Zn} / \\
\left(\mu \mathrm{g} \mathrm{g}^{-1}\right) \\
\end{array}$ & D & $\begin{array}{c}\mathrm{Co} / \\
\left(\mathrm{ng} \mathrm{g}^{-1}\right)\end{array}$ & RSD & $\begin{array}{c}\text { Mo / } \\
\left(\mathrm{ng} \mathrm{g}^{-1}\right)\end{array}$ & $\mathrm{r}$ & $\begin{array}{c}\mathrm{Pb} / \\
\left(\mathrm{ng} \mathrm{g}^{-1}\right) \\
\end{array}$ & RSD & $\begin{array}{c}\mathrm{P} / \\
\left(\mathrm{ng} \mathrm{g}^{-1}\right) \\
\end{array}$ & $\mathrm{r}$ \\
\hline$-\mathrm{a}$ & 6.36 & 6.3 & 48.52 & 2.0 & 0.80 & 4.0 & 8.93 & 2.6 & 1.79 & 0.3 & 12.77 & 1.0 & 0.84 & 4.7 & $<0.24$ & - & $<17.9$ & - & $<7.65$ & - & 852 & 6.0 \\
\hline$-b$ & 6.10 & 0.9 & 347.27 & .0 & 1.06 & 1.4 & 7.11 & .5 & 2.46 & 0 . & 96 & 0.7 & 31 & 10.7 & $<0.24$ & - & 7.9 & - & 81.2 & 2 & 07 & 7.3 \\
\hline -c & 5.82 & 2.7 & 92.31 & 0.8 & 0.91 & 3.2 & 2.32 & 0.5 & 1.74 & 0 & 51 & - & 0.26 & - & & 1.8 & 24.93 & 17.3 & 16.52 & 0.5 & & 1.6 \\
\hline $1-\mathrm{d}$ & 12.63 & 0.6 & 1495.20 & 2.8 & 0.71 & 3.0 & 4.42 & 0.5 & 1.83 & 0.1 & 36.62 & 0.5 & $<0.26$ & - & 16.25 & 1.0 & $<17.9$ & - & 51.97 & .5 & & 0.5 \\
\hline -e & 14.51 & 1.4 & 77.07 & 0.6 & 0.53 & 3.0 & & 0.3 & & 0 & & 1.3 & $<0.26$ & - & & 0.1 & & 5.1 & & 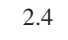 & & 2.5 \\
\hline $1-f$ & 23.48 & 1.7 & 10528.89 & 0.3 & 2.41 & 1.1 & 20.16 & 0.7 & 58.81 & 0.9 & 27692.07 & 0.5 & 6.79 & 0.8 & 115.5 & 16.9 & $<17.9$ & - & 413.58 & 0.7 & 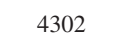 & 1.0 \\
\hline l-g & 215.15 & 0.6 & b & 0.3 & - & - & 97.54 & 0.2 & 10.2 & 0.4 & 1645.83 & 1.3 & 1.43 & 1.0 & 110.14 & 1.5 & 203.38 & 3.6 & 101.36 & 0.4 & 17192979 & 0.3 \\
\hline $1-h$ & 2.94 & 2.7 & 489.99 & 1.1 & 0.60 & 3.1 & 3.69 & 0.6 & & 0.2 & & 0.6 & $<0.26$ & - & 43.77 & 2.1 & 110.54 & te & 19 & 2.0 & & 2.9 \\
\hline $1-\mathrm{i}$ & 237.46 & 6.1 & 69.82 & 0.3 & 1.77 & 10.8 & 18.52 & 1.0 & 20. & 7.0 & $<0<-2$ & 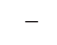 & $<0.26$ & - & 44 & 1.2 & 7.9 & _- & $<7$ & - & 13 & 3.0 \\
\hline$-j$ & 78.81 & 1.9 & 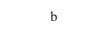 & 0.7 & - & - & 47.85 & 0.3 & 1 & 0. & 6 & 0.5 & 1.80 & 1.3 & 59 & 17.8 & 255.01 & 0.4 & 185.43 & 0.4 & & 1.0 \\
\hline $1-\mathrm{k}$ & 237.46 & 6.1 & 69.82 & 0.3 & 1.77 & 10.8 & 18.52 & 1.0 & 20. & 7.0 & & - & $<0.26$ & - & 44 & 2.7 & & - & & 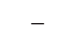 & & 3.0 \\
\hline $1-1$ & 2.20 & 1.0 & 23.11 & 1.0 & 0.92 & 11.5 & 2.61 & 0.4 & 0 & 1. & & 0.5 & 0. & 0.8 & & 1.9 & & 0.5 & 150.09 & 0.1 & & .1 \\
\hline $1-m$ & 15.49 & 0.9 & 73.52 & 1.2 & 1.12 & 6.8 & 16.1 & 0.2 & 0.9 & 1.0 & & 1.4 & 1.6 & 1.8 & & 2.7 & & 0.1 & 108 & & & 0.1 \\
\hline $1-n$ & 6.15 & 1.0 & 204.60 & 1.1 & 0.54 & 13.1 & 33.04 & 0.3 & 1.7 & 0.4 & 256 & 1.1 & 0.80 & 1.3 & 102.02 & 1.6 & 42. & 0.1 & 256.33 & 0.1 & & 0.1 \\
\hline-0 & 7.30 & 0.8 & 61.64 & 0.3 & 0.56 & 8.3 & 8.94 & 1.2 & 0. & 1.2 & 51 & 1.0 & 1.32 & 1.0 & & 2.1 & 28 & 0.1 & 28 & 0.4 & & 0.1 \\
\hline$-p$ & 82.6 & 1.5 & b & 0.6 & - & - & 46.24 & 0.3 & & 0 . & & 1 & & 0.8 & 2 & 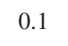 & & 0.1 & & 1 & & 0.1 \\
\hline $1-q$ & 24.31 & 1.9 & 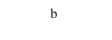 & 0.5 & - & - & 11.28 & 1.0 & 3. & 0.7 & 7 & 1.3 & 11.26 & 1.2 & & 0.1 & $<17.9$ & - & $<7.65$ & - & 2. & 0.1 \\
\hline$-r$ & 181.19 & 0.8 & 15.36 & .7 & 0.59 & 2.2 & 14.52 & 2.7 & 0. & 0.8 & 152 & 0.3 & 2 & 0.9 & 14 & 0.1 & $<$ & 0.1 & 22 & 0.1 & & .1 \\
\hline $2-\mathrm{a}$ & 80.27 & 1.5 & 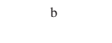 & 1.5 & - & - & 26.03 & 2.3 & 3.2 & 0.9 & 274 & 0.4 & 2.78 & 1.6 & $<0.24$ & . & 65.34 & 4.3 & .11 & 0.5 & 2674606 & 0.8 \\
\hline -b & 28.90 & 2.7 & 99.63 & 1.6 & 0.63 & 17.5 & 28.88 & 1.4 & 1.8 & 0.4 & 106 & 0.9 & 0.68 & 2.9 & $<0.24$ & - & 18 & 1.7 & 28. & 5.0 & $<$ & - \\
\hline $2-c$ & 27.98 & 3.3 & 106.46 & 1.3 & 0.73 & 3.7 & & 1.5 & & 0. & & 2.2 & $<0.26$ & - & 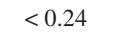 & - & & 7.2 & & 0.7 & & 6.5 \\
\hline 2-d & 65.92 & 1.4 & 143.57 & 1.3 & 0.69 & 1.9 & 93.07 & 2.4 & 2.8 & 0.4 & 14. & 1.7 & 0.88 & 5.7 & 29.28 & 23.2 & $<17.9$ & 0.8 & 350.05 & 2.2 & 20 & 9.4 \\
\hline -e & 24.3 & 0.8 & 208.65 & 1.1 & 1.61 & 8.5 & 1 & 0.8 & & 0 & & 1.1 & & 1.5 & & 8.0 & & & & & & .9 \\
\hline $2-f$ & 5.52 & 2.7 & 36.79 & 0.5 & 0.52 & 5.2 & 4.93 & 1.6 & 4. & 0.3 & 9 & 0.7 & $<0.26$ & - & & 69.1 & $<$ & 6.8 & 97 & 1.4 & 11 & 1.2 \\
\hline $2-\mathrm{g}$ & 33.95 & 1.0 & 284.16 & 0.6 & 1.33 & 0.9 & 14.41 & 0.7 & 15.2 & 0.6 & 1. & 0.3 & 2.24 & 1.2 & 34 & 3.3 & 173.21 & 2.6 & 51 & 4 & & 8.1 \\
\hline 2-h & 14.95 & 2.0 & 30.73 & 0.3 & 0.1 & 4.0 & 3.63 & 0.8 & & 0. & & 2.0 & $<0.26$ & - & 162.67 & 56.4 & ד & 3.0 & 154.41 & 22.6 & & 5.6 \\
\hline $2-\mathrm{i}$ & 764.99 & 9.9 & 8643.35 & 9.3 & 0.037 & - & $<0.13$ & - & $<0.031$ & - & $<0$ & - & $<0.26$ & - & 163.48 & 0.4 & $<17.9$ & - & $<7.65$ & - & $<62.8$ & - \\
\hline & & 6 & & 3 & & 7.4 & & 0 & & 0.4 & & 0. & & & & 0.1 & & 0.1 & & 0.1 & & 0.1 \\
\hline $2-k$ & 2 & 2.3 & 308.02 & 2.2 & 0.49 & 9.8 & 4.02 & 2.5 & 1 . & 0.8 & 21 & 1.3 & 1. & 2.0 & 17 & 0.1 & 18 & 0.1 & 23 & 0.1 & 43 & 0.1 \\
\hline $2-1$ & 4 & 1.9 & 30.90 & 2.2 & 0.62 & 7.8 & 3 & 5 & 0.7 & 0.5 & 1 & 0 & 0.54 & 1.1 & 1 & .1 & 19.65 & 1 & 69 & 0.1 & 13 & 0.1 \\
\hline $2-m$ & 62.76 & 0.6 & 44.60 & 0.6 & 0.95 & 6.7 & 20.27 & 0.8 & & 0. & 612 & 0.8 & & 1.4 & & 0.1 & 9 & 0.0 & & .1 & 60 & 0.1 \\
\hline $2-n$ & 185.54 & 7.0 & b & 1.3 & $<0.037$ & 7.4 & 92.47 & 1.7 & 76 & 0.5 & 52 & 2.2 & 1.94 & 1.9 & 108.33 & 0.1 & 244.39 & 0.0 & 139.28 & 0.1 & 1270 & 0.1 \\
\hline 2-o & 0.45 & 101.1 & 131.38 & 0.2 & & 0.8 & & 0.5 & & 0.1 & & 0.8 & $<0.26$ & - & 7356.62 & 88.4 & 05.35 & 6.7 & 3713.27 & 0.6 & & 1.8 \\
\hline $2-p$ & 186.85 & 4.8 & 67.74 & 0.3 & 3.67 & 47.0 & 7.78 & 1.7 & $<0.031$ & - & $<0.51$ & 1.9 & $<0.26$ & - & 5.82 & 5.8 & 175.15 & 13.7 & 86.70 & 1.7 & 1122 & 6.5 \\
\hline $3-\mathrm{a}$ & 80.13 & .4 & 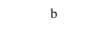 & - & 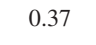 & 6.1 & 28.30 & 0.5 & & 0.7 & & 0.9 & 4.09 & 0.8 & & 70.4 & & 28.1 & 25 & 11.4 & 326 & 0.9 \\
\hline 3-b & 375.06 & 1.4 & b & - & 0.0 & - & 172.02 & 0.6 & 13. & 2.4 & 295 & 1.0 & & 1.1 & & 17.2 & 35 & 5.5 & & 5.7 & 105 & 1.7 \\
\hline $3-\mathrm{c}$ & 53.83 & 1.3 & b & - & 02 & 3.8 & 10.62 & 0.4 & 20 & 0.2 & 319.97 & 0.8 & 21.72 & 0.7 & 62 & 4.0 & 5 & 2.0 & 47 & 4.4 & 3364933 & 1.5 \\
\hline $3-d$ & 9.82 & 1.3 & 163.32 & 1.0 & 0.03 & - & 5.58 & 0.4 & & 0. & & 0.7 & $<0.26$ & - & & 1.0 & .9 & 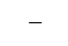 & & .0 & & 5.9 \\
\hline $3-\mathrm{e}$ & 5.75 & 8.3 & 95.57 & 1.4 & 0.75 & 0.8 & 5.33 & 0.7 & 169 & 0.2 & 1.65 & 3.6 & $<0.26$ & - & 46.83 & 90.1 & 738 & 2.5 & 87 & 3.1 & $<62.8$ & - \\
\hline 3-f & 177.30 & 11.5 & 114.70 & 1.8 & 4.67 & 3.3 & 11.93 & 0.7 & & 14.5 & $<0$ & - & $<0.26$ & - & 651.05 & 21.4 & $<17.9$ & - & $<1$ & - & $<62.8$ & - \\
\hline $3-\mathrm{g}$ & 3258.46 & 1.9 & 54057.03 & 1.2 & 4.78 & 3.6 & 40.81 & 1.0 & 2.8 & 3.4 & $<0$ & - & $<0.26$ & - & 550.12 & 18.0 & $<17.9$ & - & & - & $<62.8$ & - \\
\hline 3-h & 32 & 4.1 & 9 & 1.9 & 0.36 & 0.9 & 75 & 1.2 & 74.67 & 0.7 & 4586 & 0.6 & 0.71 & 1.4 & 360.46 & 0.1 & $<1<1$ & - & 123.08 & 0.1 & 217 & 0.1 \\
\hline . & 306.27 & 3.1 & . & - & 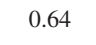 & 11.6 & 60.10 & 0.4 & & 0.3 & 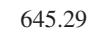 & 1.4 & & 3.1 & 7 & 0.1 & $<17.9$ & - & & - & 11 & 0.1 \\
\hline $3-\mathrm{j}$ & 23.85 & 2.3 & 101.86 & 0.2 & 0.55 & 7.9 & 92.36 & 0.8 & 128.06 & 1.0 & 42175.90 & 1.4 & 1.15 & 1.7 & 110.15 & 0.1 & 18.44 & 0.1 & 170.86 & 0.1 & 121 & 0.1 \\
\hline $3-\mathrm{k}$ & 8.52 & 5.0 & 29.35 & 1.1 & 0.68 & 13.3 & 14.85 & 0.4 & & 0.8 & 85.69 & 2.3 & 0.63 & 1.2 & 41.39 & 0.2 & 42.84 & 0.1 & 172.78 & 0.1 & 320 & 0.1 \\
\hline $3-1$ & 1.91 & 3.7 & 21.38 & 1.0 & 6 & 4.9 & 2.24 & 0.9 & & 0.6 & & 1.2 & 0.58 & 1.4 & & 0.1 & $<17$ & - & & 0.1 & $<62.8$ & 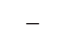 \\
\hline SIIII & 1.69 & 0.6 & 19.87 & 1.0 & 0.31 & 9.8 & 3.53 & 0.7 & & 0.2 & 522.34 & 1.1 & 0.60 & 0.9 & 12.02 & 0.1 & $<17.9$ & - & 181.41 & 0.1 & 1916 & 0.1 \\
\hline $3-n$ & 57.92 & 0.6 & 42.67 & 0.1 & 2.91 & 7.1 & 126.92 & 0.3 & 11.47 & 0.9 & 175.70 & 1.0 & 4.32 & 0.4 & 83.84 & 1.2 & 29.83 & 0.1 & 403.92 & 0.1 & 1926 & 0.1 \\
\hline 3-o & 157.36 & 11.1 & & 1.1 & & & 9.58 & 0.7 & & 1.2 & & 0.1 & 88 & 1.2 & & 0.1 & & - & & 0.1 & 1014 & 0.1 \\
\hline $3-n$ & 16.70 & 0.6 & 21.55 & 3.4 & 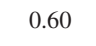 & 10.2 & 6.69 & 0.8 & & 0.4 & 4 & 0.8 & 0.59 & 0.5 & 19.17 & 0.1 & $<17.9$ & - & 88 & 0.1 & 65 & 0.1 \\
\hline $3-q$ & 3934.29 & 1.5 & 1452.65 & 1.1 & 23.67 & 3.5 & 308.88 & 0.5 & 318.61 & 0.7 & $<0.51$ & - & $<0.26$ & - & $<0.24$ & - & $<17.9$ & - & $<7.65$ & - & 18666 & 1.6 \\
\hline $3-r$ & 383.85 & 6.6 & 96.70 & 0.9 & 1.29 & 131.7 & 721.90 & 0.6 & 24.11 & 14.2 & $<0.51$ & - & $<0.26$ & - & 20.7 & 1.0 & $<17.9$ & - & $<7.65$ & - & 431783 & 0.9 \\
\hline
\end{tabular}

${ }^{\mathrm{a}} \mathrm{RSD}$ is the relative standard deviation of 3 replicates; bsaturated signal. 
Table 6. Pearson's correlations for $\mathrm{Al}, \mathrm{Ca}, \mathrm{Cu}, \mathrm{Fe}, \mathrm{Mn}, \mathrm{Mg}, \mathrm{Zn}, \mathrm{Mo}, \mathrm{Co}, \mathrm{Pb}$ and $\mathrm{P}$ concentrations in cocaine samples

\begin{tabular}{|c|c|c|c|c|c|c|c|c|c|c|c|}
\hline & $\mathrm{Al}$ & $\mathrm{Ca}$ & Co & $\mathrm{Cu}$ & $\mathrm{Fe}$ & $\mathrm{Mn}$ & $\mathrm{Mg}$ & Mo & $\mathrm{Pb}$ & $\mathrm{P}$ & $\mathrm{Zn}$ \\
\hline $\mathrm{Al}$ & 1.00 & & & & & & & & & & \\
\hline $\mathrm{Ca}$ & -0.025 & 1.00 & & & & & & & & & \\
\hline Co & 0.279 & 0.114 & 1.00 & & & & & & & & \\
\hline $\mathrm{Cu}$ & 0.817 & -0.169 & 0.081 & 1.00 & & & & & & & \\
\hline $\mathrm{Fe}$ & 0.618 & 0.257 & 0.017 & 0.700 & 1.00 & & & & & & \\
\hline $\mathrm{Mn}$ & 0.658 & -0.078 & 0.013 & 0.851 & 0.740 & 1.00 & & & & & \\
\hline $\mathrm{Mg}$ & -0.064 & 0.029 & 0.062 & -0.023 & 0.142 & 0.362 & 1.00 & & & & \\
\hline Mo & -0.033 & 0.311 & 0.192 & -0.050 & 0.005 & -0.038 & -0.031 & 1.00 & & & \\
\hline $\mathrm{Pb}$ & -0.249 & -0.052 & -0.181 & -0.164 & -0.022 & -0.128 & 0.107 & 0.169 & 1.00 & & \\
\hline $\mathrm{P}$ & 0.002 & 0.600 & 0.085 & -0.121 & 0.385 & -0.039 & -0.073 & 0.130 & -0.036 & 1.00 & \\
\hline $\mathrm{Zn}$ & -0.115 & 0.463 & -0.050 & -0.095 & -0.010 & -0.052 & 0.094 & 0,095 & 0.209 & 0.041 & 1.00 \\
\hline
\end{tabular}

$\mathrm{P}$ concentrations ranged from values below the limit of detection to $105000 \mu \mathrm{g} \mathrm{g}^{-1}$. Only eight samples (R1-g and R1-p, R2-a and R2-n, R3-a, R3-b, R3-c and R3-i) exhibited $\mathrm{P}$ concentration higher than $1000 \mu \mathrm{g} \mathrm{g}^{-1}$. All those samples also had high Ca concentration, indicating the use of calcium phosphate as diluent. This behavior may explain the significant Person correlation observed between $\mathrm{Ca}$ and $P$ concentrations $(r=0.6)$.

Concentrations of $\mathrm{Al}$ ranged from 0.45 to $3934 \mu \mathrm{g} \mathrm{g}^{-1}$ and nine samples had $\mathrm{Al}$ concentration higher than $200 \mu \mathrm{g} \mathrm{g}^{-1}$. The high amount of $\mathrm{Al}$ in those samples could be related to the use of white clay as a drug diluent. White clay is a natural material, composed by hydrated silicates of aluminum and iron and can contain specific contaminants like $\mathrm{Mn}, \mathrm{Cu}$, and $\mathrm{Pb}$. This may explain the high correlation between $\mathrm{Al}$ and $\mathrm{Cu}(\mathrm{r}=0.817), \mathrm{Al}$ and $\mathrm{Fe}(\mathrm{r}=0.618), \mathrm{Al}$ and $\mathrm{Mn}(\mathrm{r}=0.658), \mathrm{Cu}$ and $\mathrm{Fe}(0.70), \mathrm{Cu}$ and $\mathrm{Mn}(0.851)$ and $\mathrm{Fe}$ and $\mathrm{Mn}(0.740)$, as can be seen in Table 6 .

$\mathrm{Mn}, \mathrm{Cu}$, and $\mathrm{Zn}$ were present at intermediate concentrations in comparison to the other elements, ranging from below LODm to $30 \mu \mathrm{g} \mathrm{g}^{-1}$. All samples had Mn concentration below $20 \mu \mathrm{g} \mathrm{g}{ }^{-1}$, except for R1-f, R3-j, and R3-q. The higher Mn concentration in those three samples suggest the use of potassium permanganate during the production process to obtain cocaine in its base form. It could also be explained by the use of talcum powder as diluent since, in R1-f and R3-j samples, the Mg concentration was also very high; however, no significant correlation was observed for $\mathrm{Mg}$ and $\mathrm{Mn}(\mathrm{r}=0.362)$ in this study.

$\mathrm{Co}$ and $\mathrm{Pb}$ were found in very low concentrations, reaching a maximum of 17.4 and $3.7 \mu \mathrm{g} \mathrm{g}^{-1}$, respectively. These low concentrations indicate the presence of $\mathrm{Co}$ and $\mathrm{Pb}$ in reagents and adulterants used in the drug production process. Mo also exhibited low concentrations, reaching a maximum of $12.1 \mu \mathrm{g} \mathrm{g}^{-1}$. This has occurred because Mo is not presented at significant concentration in drug adulterants usually. Instead, Mo is a plant micronutrient so that it may be related to the purity of the drug. In other words, the higher the Mo concentration, the less dilution the drug may have suffered. ${ }^{21}$

Magalhães et al..$^{23}$ quantified inorganic elements in street cocaine samples seized in Minas Gerais and Amazonas, states of Brazil. As well as our results, $\mathrm{Ca}, \mathrm{P}$ and $\mathrm{Mg}$ maximum concentrations were higher than the other elements investigated, as can be seen on Table 7 . Except for $\mathrm{Al}, \mathrm{P}, \mathrm{Co}$ and $\mathrm{Cu}$, the maximum concentration of the inorganic elements was lower than the maximum concentration found in this study. For example, the $\mathrm{Ca}$, $\mathrm{Mg}, \mathrm{Pb}$, and $\mathrm{Zn}$ maximum concentrations in such samples were, respectively, 3.6, 2.3, 5.1, and 39.4 times higher than those found in this study.

Liu et al. ${ }^{39}$ also determined inorganic elements in cocaine samples seized in China. As well as our results,

Table 7. Comparison of results

\begin{tabular}{lccc}
\hline \multirow{2}{*}{ Element } & \multicolumn{3}{c}{ Maximum concentration $/\left(\mu \mathrm{g} \mathrm{g}^{-1}\right)$} \\
\cline { 2 - 4 } & This study & Magalhães et al..$^{23}$ & Liu et al. ${ }^{39}$ \\
\hline $\mathrm{Al}$ & 3934.3 & 304.0 & 571.0 \\
$\mathrm{Mo}$ & 12.1 & 17.7 & 0.2 \\
$\mathrm{P}$ & 105165.0 & 47100.0 & non-measured \\
$\mathrm{Pb}$ & 3.7 & 18.9 & 203.7 \\
$\mathrm{Zn}$ & 21.7 & 855.0 & 475.0 \\
$\mathrm{Ca}$ & 10528.9 & 38100.0 & 201743.0 \\
$\mathrm{Mg}$ & 45869.9 & 107000.0 & 17517.0 \\
$\mathrm{Fe}$ & 308.9 & 349.0 & 186.2 \\
$\mathrm{Mn}$ & 318.6 & 464.0 & 36.4 \\
$\mathrm{Co}$ & 17.4 & 10.0 & 0.7 \\
$\mathrm{Cu}$ & 23.7 & 14.2 & 13.6 \\
\hline
\end{tabular}


$\mathrm{Ca}$ and $\mathrm{Mg}$ concentrations were higher than those of the other elements investigated. For Al, Mn, Mo and Co, the authors found, respectively, a maximum concentration of almost 7, 9, 61 and 25 times lower than of this study and for $\mathrm{Pb}$ and $\mathrm{Zn}$, almost 55 and 22 times higher, respectively.

Frequency histograms of the number of samples that presented concentration of the studied elements in different ranges of values are shown in Figure 1. The histogram allows a better understanding about the concentration profiles in cocaine samples. It can be seen that, for $\mathrm{P}$ element, for example, most of the samples presented similar and low concentration of this element and just a few of them presented higher concentrations. In general, most of the samples exhibited concentrations of elements investigated in a low value range, however some samples showed very discrepant concentrations. This pattern can be observed for all analyzed elements, except for $\mathrm{Pb}$, which concentration profile was slightly more heterogeneous, since many samples showed concentrations in different ranges.
This pattern was also observed by Magalhães et al. ${ }^{23}$ and Liu et al. ${ }^{39}$ who reported that some cocaine samples had discrepant concentrations of investigated elements. From 180 analyzed samples, according to Liu et al.,${ }^{39} 45$ of them were considered as outliers, because of the discrepant element concentrations found.

\section{Chemometrics analysis}

Multivariate analysis, HCA and PCA, of the concentration of investigated elements was carried out in order to classify the cocaine samples according to their similarities and differences. Since variables (elements concentrations) has different orders of magnitude, the normalization procedure, before multivariate analysis, was essential to prevent one variable from overlapping another.

For PCA results, the first three principal components explained only $61.2 \%$ of the total data variance. This low capture of the variance occurred because most of the
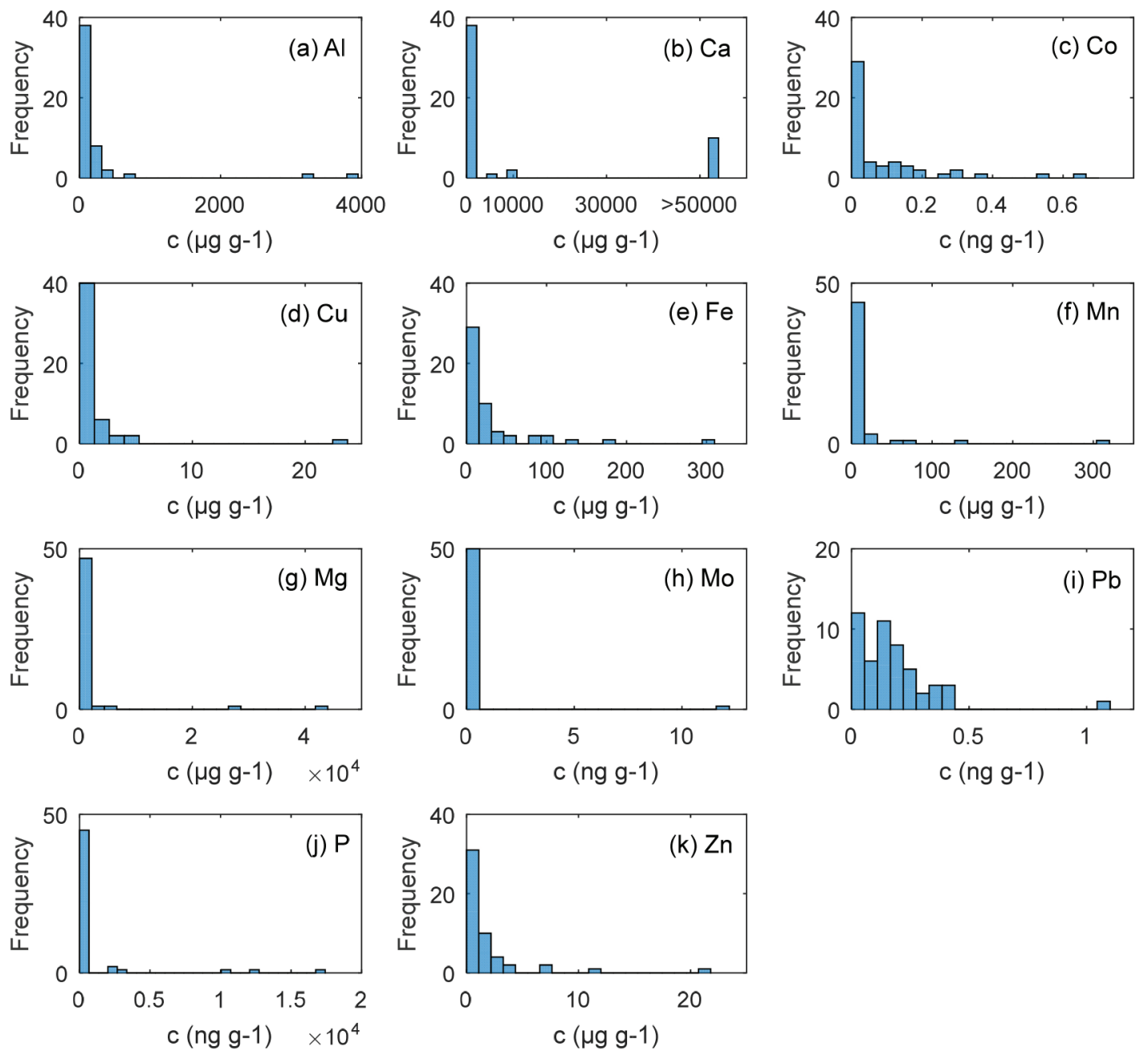

Figure 1. Histogram of elements concentrations in street cocaine samples. 
variables were not correlated, as can be seen in Table 6 . In this case, variables reduction in principal components can be inefficient. From the loadings of features in PC1, $\mathrm{PC} 2$ and PC3, the more correlated variables $\mathrm{Al}, \mathrm{Cu}, \mathrm{Fe}$, and $\mathrm{Mn}$ were the dominating features in the first principal component; $\mathrm{Ca}$ and $\mathrm{P}$ dominate in the second and $\mathrm{Co}, \mathrm{Mg}$ and $\mathrm{Pb}$ dominate in the third principal component.

The 3D plot of PC1, PC2, and PC3 is shown in Figure 2. The first three components cannot discriminate the cocaine samples in different regions, through the concentration of elements. The plot shows that almost all samples are located in the center of the box, and some few samples, especially from region 3, are located far from the center. Samples close to the center are those in which the concentration of the elements is close to the average. On the other hand, samples far from center, showed greater variation in concentrations, differing from the others. Chan et al. ${ }^{31}$ also carried out PCA in 309 heroin samples, using 16 inorganic elements concentration, in order to classify them according to the distribution lines. The score plot presented the samples clustered into two dense areas, indicating that samples were likely from at least two major distribution lines.

In HCA analysis, the dendrogram obtained (Figure 3a) reveled the similarity or difference between the samples, as well as the distance levels between the clusters. Four groups were formed at a linkage distance of 8 (dashed line). This groups contained 36, 3, 10 and 1 samples, respectively. As can be seen in the dendrogram, the largest group contains samples from the three seizure regions, showing no significant differences in the drugs from these regions.

According to PCA and HCA results, the samples presented a very similar inorganic profile, so it was not possible to separate them, with respect to the three seizure regions. It became clear that no patterns of adulteration were detected in the drug samples. For this reason, it was not possible to classify them in different groups in this illicit market. Only similarities were found in the impurity content, which was not enough to classify the samples. The small extension of the state of Espírito Santo can be a reason for the similarity between samples. It can also be considered that, although we have worked with a relatively high number of samples for this type of work (52 street cocaine samples seized), perhaps a larger number of samples could lead to the observation of some trend.

Different from the above, Myors et al. ${ }^{40}$ built HCA models capable of indicate the heroin sample origins by only considering the inorganic elements distribution, analyzed by coupled plasma mass spectrometry. The dendogram placed together the samples from one specific region and separated from the samples from other parts of the world. However, the authors used data of 73 inorganic compounds and a total of 188 heroin samples, numbers much higher than we used in this research. Liu et al..$^{41}$ also could discriminate 150 heroin samples according to two geography origins, using measurements of 19 inorganic trace elements and a two-dimensional score scatter plot based on PCA analysis.

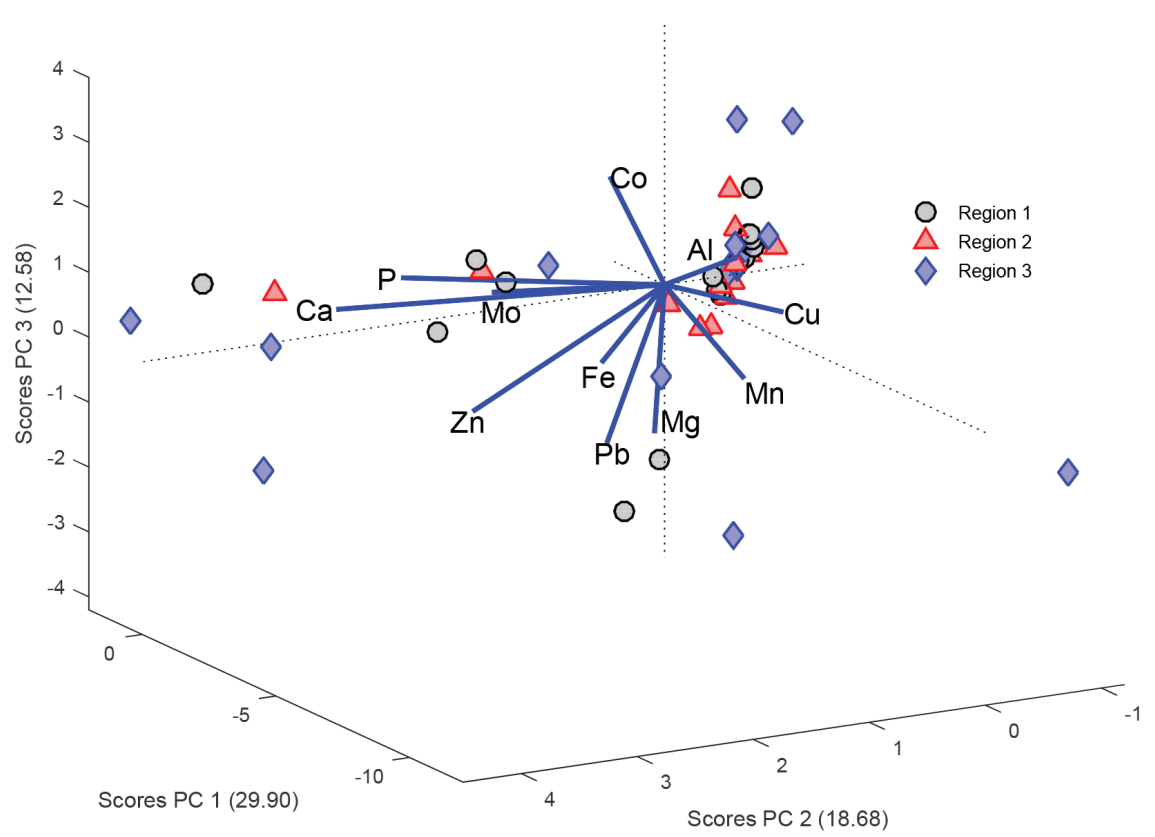

Figure 2. Scores plots of first three principal components (PC1, PC2, and PC3) for inorganic elements concentrations in cocaine samples. 

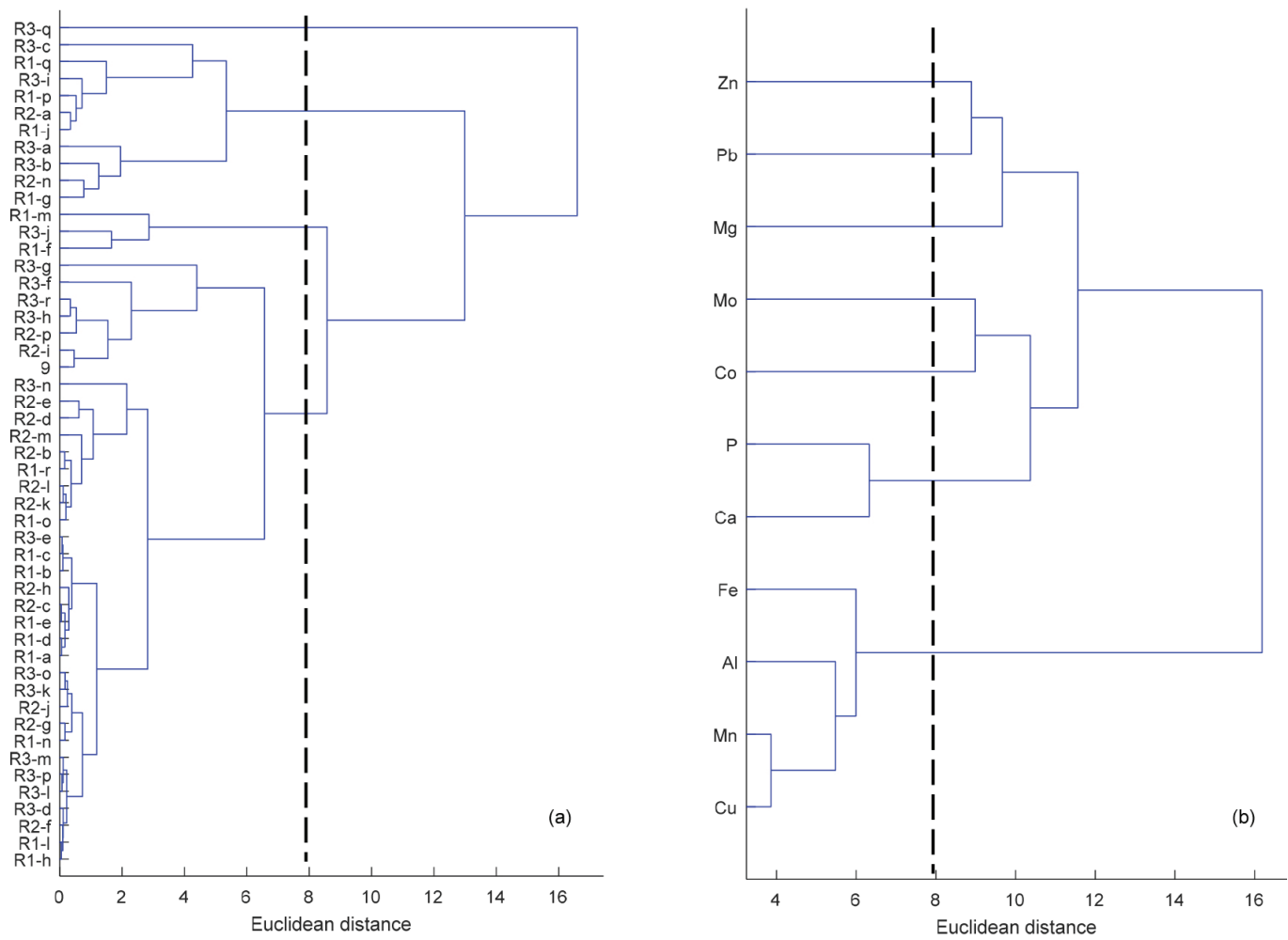

Figure 3. Dendrogram of samples (a) and variables (b) obtained by the Euclidean distance and the Ward's method.

For future researches, we recommend to develop a methodology to purify the cocaine samples and analyze impurities and purified cocaine, separately. Maybe that could show by chemometrics analysis the traces of the different cultivars, indicating their origin, as well as those coming from one or more drug producing and/or supplying regions. Besides, this data could also be combined with measurements of organic compounds to provide a more powerful discriminating technique.

Cluster analysis was also performed on the 11 measured elements. According to the dendogram shown in Figure $3 \mathrm{~b}, \mathrm{Al}, \mathrm{Cu}, \mathrm{Fe}$ and $\mathrm{Mn}$, which were highly correlated (Table 6), were grouped in a single cluster while, $\mathrm{P}$ and $\mathrm{Ca}$ that were significantly correlated were in another group. The other elements, which did not have significant correlation between them, became separated. The elements concentrations (Table 5) were summed to calculate the percentage $\left(\mathrm{m} \mathrm{m}^{-1}\right)$ of them in each cocaine sample. Figure 4 shows a boxplot of the total concentration in samples, separated by the seizure regions.

The total concentration in samples from region 3 reveals more dispersion, followed by region 1 . Besides, the data are asymmetric, due to the distortion caused by the extremely high concentrations of some elements in some samples. These results evidenced that, in general, samples from region 3 suffered more dilution, whereas samples from region 2 did lower dilution.

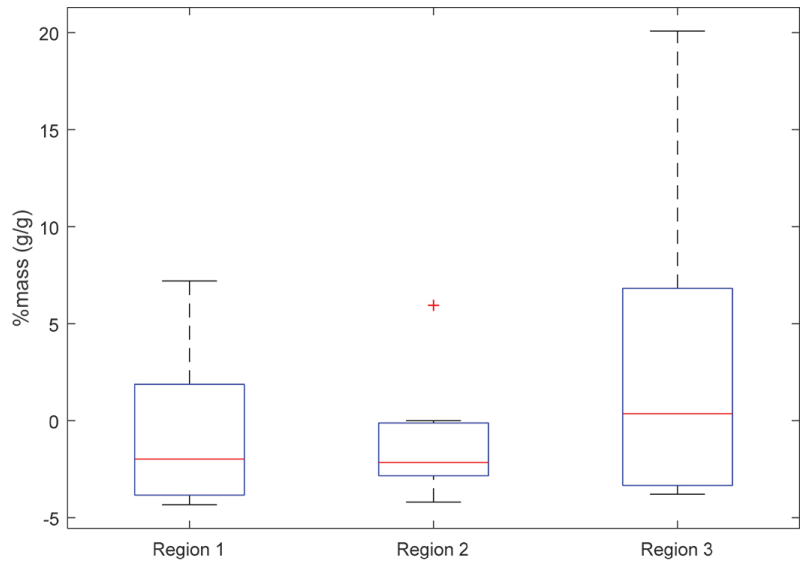

Figure 4. Boxplot of total concentration $\left(\mathrm{m} \mathrm{m}^{-1}\right)$ of investigated elements in the street cocaine samples, by seizure regions.

\section{Conclusions}

Fifty-two samples of street cocaine, seized in different cities of State of Espírito Santo, were analyzed, and concentration results were used to determine inorganic profiles through chemometrics treatments. The method used to quantify $\mathrm{Al}, \mathrm{Ca}, \mathrm{Cu}, \mathrm{Fe}, \mathrm{Mn}, \mathrm{Mg}$, and $\mathrm{Zn}$ by ICP OES and $\mathrm{Mo}, \mathrm{Co}, \mathrm{Pb}$ and $\mathrm{P}$ by ICP-MS, after microwave assisted acid decomposition, proved to be appropriated, since the results from recovery tests were within an acceptable range. Multivariate analysis allowed to correlate the inorganic analytes and propose some substances that may have been 
used during cocaine production or its dilution.

The profile of the samples with respect to the investigated elements was very similar, according to HCA and PCA and they could not be discriminated by region. This result is not surprising since Espírito Santo is a small extension state. Some samples exhibited high and discrepant concentrations of some studied elements indicating a high level of dilution. Most of those samples were from region 3.

\section{Acknowledgments}

The authors are grateful to Civil Police of Espírito Santo State, FAPES (37372.591.18380.05102018, Edital CNPq/FAPES No 23/2018-Programa de Apoio a Núcleos Emergentes (PRONEM) Outorga 597/2018), and CNPq (305359/2017-7 and 422555/2018-5) for financial support. Also, the authors would like thanks LabPetro/UFESResearch and Methodology Development Laboratory for Crude Oil Analysis for supporting this study. This study was financed in part by the Coordenação de Aperfeiçoamento de Pessoal de Nível Superior-Brazil (CAPES)-finance code 001.

\section{Author Contributions}

Zanata B. Amorim was responsible for conceptualization, data curation, writing original draft, sample preparation and analysis; Maiara P. Machado for data curation and writing original draft; Mariana K. Moro for writing original draft and writing-review and editing; Laura O. Rebouças for data curation, writing-review and editing, sample preparation and analysis; Bruna M. Dalfior for analysis, data curation and writing-review; Wanderson Romão for conceptualization and writing-review and editing; Paulo Roberto Filgueiras for conceptualization and writing-review and editing; Maria Tereza W. D. Carneiro for conceptualization and writing-review and editing; Geisamanda P. Brandão for conceptualization, formal analysis funding acquisition, project administration and writing-review and editing.

\section{References}

1. Montangne, M. In The Epidemiology of Cocaine Use and Abuse; Schober, S.; Schade, C., eds.; National Institute on Drug Abuse: Rockville, Maryland, 1991.

2. Wright, M. G. M.; Gliksman, L.; Khenti, A.; Furegato, A. R. F.; Rev. Latino-Am. Enfermagem 2009, 17, 751.

3. World Drug Report; United Nations Publication, Sales No. E.19. XI.8, 2019, available at https://wdr.unodc.org/wdr2019/, accessed in July 2020.
4. Farias, R.; Introdução à Química Forense, $2^{\text {nd }}$ ed.; Editora Átomo: São Paulo, 2008.

5. Romão, W.; Schwab, N. V.; Bueno, M. I. M. S.; Sparrapan, R.; Eberlin, M. N.; Martiny, A.; Sabino, D.; Maldaner, A. O.; Quim. Nova 2011, 34, 1717.

6. Conceicão, V. N.; Souza, L. M.; Merlo, B. B.; Filgueiras, P. R.; Poppi, R. J.; Romão, W.; Quim. Nova 2011, 37, 1538.

7. Casale, J. F.; Klein, R. F. X.; Forensic Sci. Rev. 1993, 5, 95.

8. Bernardo, N. P.; Siqueira, M. E. P. B.; Paiva, M. N. J.; Maia, P. P.; Int. J. Drug Policy 2003, 14, 331.

9. Broséus, J.; Gentile, N.; Pont, F. B.; Gongora, J. M. G.; Esseiva, L. G. P.; Forensic Sci. Int. 2015, 257, 307.

10. Silva, M. J.; Anjos, E. V.; Honorato, R. S.; Pimmentel, M. F.; Paim, A. P. S.; Anal. Chim. Acta 2008, 629, 736.

11. Dujourdy, L.; Besacier, F.; Forensic Sci. Int. 2008, 179, 111.

12. Fucci, N.; Forensic Sci. Int. 2007, 172, 35.

13. Weiner, A. I.; Bayer, M. J.; Mckay Jr., C. A.; Demeo, M.; Starr, E.; Am. J. Emerg. Med. 1998, 16, 517.

14. Behrman, A. D.; J. Emerg. Nurs. 2008, 34, 80.

15. Coomber, R.; Addict. Res. Theory 2001, 5, 195.

16. Silva Jr., R. C.; Gomes, C. S.; Goulart Jr., S. S.; Almeida, F. V.; Grobério, T. S.; Braga, J. W. B.; Zacca, J. J.; Vieira, M. L.; Botelho, E. D.; Maldaner, A. O.; Forensic Sci. Int. 2012, 221, 113.

17. Carvalho, D. G.; Mídio, A. F.; Braz. J. Pharm. Sci. 2003, 39, 71.

18. Bermejo-Barrera, P.; Moreda-Piñeiro, A.; Moreda-Piñeiro, J.; Bermejo-Barrera, A.; Talanta 1996, 43, 77.

19. Bermejo-Barrera, P.; Moreda-Piñeiro, A.; Moreda-Piñeiro, J.; Bermejo-Barrera, A.; Bermejo-Barrera, A. M.; J. Forensic Sci. 1999, 44, 270.

20. Bermejo-Barrera, P.; Moreda-Piñeiro, A.; Moreda-Piñeiro, J.; Bermejo-Barrera, A.; Talanta 1996, 43, 1783.

21. Bermejo-Barrera, P.; Moreda-Piñeiro, A.; Moreda-Piñeiro, J.; Bermejo-Barrera, A.; J. Anal. At. Spectrom. 1995, 10, 1011.

22. Bermejo-Barrera, P.; Moreda-Piñeiro, A.; Moreda-Piñeiro, J.; Bermejo-Barrera, A.; Anal. Chim. Acta 1995, 310, 355.

23. Magalhães, E. J.; Nascentes, C. C.; Pereira, L. S. A.; Guedes, M. L. O.; Lordeiro, R. A.; Auler, L. M. L. A.; Augusti, R.; Queiroz, M. E. L. R.; Sci. Justice 2013, 53, 425.

24. Bovens, M.; Ahrens, B.; Alberink, I.; Nordgaard, A.; Salonen, T.; Huhtal, S.; Forensic Sci. Int. 2019, 301, 82.

25. Nascimento, J. A.; Dionísio, A. G. G.; Nascimento, G. C. L.; Freitas, S. K. B.; Araújo, M. C. V.; Quim. Nova 2010, 33, 351.

26. Materazzi, S.; Gregori, A.; Ripani, L.; Apriceno, A.; Risoluti, R.; Talanta 2017, 166, 328.

27. Chudzinska, M.; Baralkiewiscz, D.; Food Chem. Toxicol. 2011, 49, 2741.

28. Ferreira, E. C.; Rodrigues, S. H. B. G.; Ferreira, M. M. C.; Nóbrega, J. A.; Nogueira, A. R. A.; Ecletica Quim. 2002, 27, 77. 
29. Neto, M. M. J.; Moita, C. G.; Quim. Nova 1998, 21, 467.

30. Nicácio, J.; Lara, P. C. P.; Silva, J. C. J.; Ciminelli, V.; Silva, J. B. B.; At. Spectrosc. 2007, 28, 1.

31. Chan, K. W.; Tan, G. H.; Wong, R. C.; Sci. Justice 2013, 53, 73.

32. Chan, K. W.; Tan, G. H.; Wong, R. C.; J. Anal. At. Spectrom. 2011, 26, 1813.

33. Watters, R. L.; Eberhardt, K. R.; Beary, E. S.; Fassett, J. D.; Metrologia 1997, 34, 87.

34. MATLAB, v.8.0 and Statistics Toolbox, v.8.1; The MathWorks, Inc., Natick, Massachusetts, United States, 2012.

35. Brito, N. M.; Junior, O. P. A.; Polese, L.; Ribeiro, M. L.; Pesticidas: Rev. Ecotoxicol. Meio Ambiente 2003, 13, 129.

36. Official Methods of Analysis of AOAC International, $18^{\text {th }}$ ed.; Horwitz, W.; Latimer Jr., G. W., eds.; AOAC: Rockville, 2011, appendix F.
37. Instituto Nacional de Metrologia, Qualidade e Tecnologia (INMETRO); DOQ-CGCRE-008 Orientação sobre Validação de Métodos Analíticos; INMETRO: Rio de Janeiro, 2016, available at http://inmetro.gov.br/Sidoq/Arquivos/Cgcre/DOQ/ DOQ-Cgcre-8_05.pdf, accessed in July 2020.

38. Chan, K. W.; Tan, G. H.; Wong, R. C. S.; Anal. Lett. 2012, 45, 1122.

39. Liu, C.; Hua, Z.; Meng, X.; Forensic Sci. Int. 2017, 276, 77.

40. Myors, R.; Wells, R. J.; Skopec, S. V.; Crisp, P.; Iavetz, R.; Skopec, Z.; Ekangakic, A.; Robertson, J.; Anal. Commun. 1998, $35,403$.

41. Liu, C.; Hua, Z.; Bai, Y.; Liu, Y.; Forensic Sci. Int. 2014, 239, 37.

Submitted: April 18, 2020

Published online: July 30, 2020 